\title{
MJN THE IMPACT OF NON-FINANCIAL INCENTIVES ON INTENTION TO STAY: A STUDY AMONG NURSES IN PRIVATE HOSPITALS IN MALAYSIA
}

\author{
Lalitha Krishnamoorthy*, Rajendran Muthuveloo, Teoh Ai Ping \\ Graduate School of Business, Universiti Sains Malaysia, Penang, Malaysia \\ *Corresponding Author’s Email: lalithak18@yahoo.com
}

\begin{abstract}
The growing aging population and the need for quality healthcare necessitate increasing demand for nurses. However, the shortage of nursing workforce remains a challenge for many hospitals. Nurse turnover continues to be as one of the factors of shortage of nurses. Incentives have been found to improve nurse retention. Specifically, non-financial incentives have shown potential as an approach addressing performance, quality of healthcare and turnover. As such, this study aims to examine the impact of nonfinancial incentives on nurses' intention to stay. A cross-sectional survey was administered to 153 registered nurses employed in private hospitals in Malaysia. Non-financial incentives were measured with eight dimensions consisting of education, training and professional development; recognition; promotional opportunities; flexible working arrangements; autonomy and control over nursing practice; manageable workload; management and supervisory support and finally, work environment. In this study, promotional opportunities, manageable workload and work environment have shown a significant positive relationship on nurses' intention to stay. Although there is no one-size-fits-all approach, hospital management may focus on creating a positive and safe work environment, formal framework for promotional opportunities and maintaining adequate nursing workforce to avoid heavy workloads among nurses. These strategies in turn, may improve nurse retention.
\end{abstract}

Keywords: Non-Financial Incentives, Nurse Retention, Registered Nurse, Nurse Shortage, Malaysia

\section{INTRODUCTION}

Shortage of manpower in nursing is becoming a major concern in many parts of the world. Ageing nursing workforce and nurses leaving the profession earlier than retirement are major concerns in most parts of the developed countries (Aiken et al., 2001; Juraschek et al., 2012; Newman \& Maylor, 2002; Torgerson et al., 2012). Developing countries, on the other hand, have similar supply shortfall but coupled with nurse migration to developed countries, seeking lucrative and better income hence creating local shortage of nurses (Atefi, Abdullah \& Wong, 2016; Efendi et al., 2017; Oda, Tsujita \& Rajan, 2018). For instance, in Saudi Arabia, relatively few choose nursing as a profession (Al-Dossary, 2018) due to the cultural values, family obligations and perceived low image of nursing (AlYami \& Watson, 2014). This phenomenon has led Saudi Arabia as one of the countries that rely heavily on expatriate nurses, with 78 percent of the nursing workforce in the kingdom are expatriate nurses (Hassan, 2017).

In Malaysia, extended longevity and increase in hypertension, cardiovascular ailments and diabetes have made the healthcare industry a powerful area of economic growth towards the nation's income (PEMANDU, 2012). This has prompted demand for excellent medical care, which has opened new opportunities within the healthcare industry in Malaysia to address the rising need. Evidently, the number of private hospitals has been rising since 1980. The number of private hospitals in Malaysia increased from 10 in 1980 (Leng \& Barraclough, 2007) to 214 private hospitals in 2013 (Ministry of Health, 2014). The increase has created more demand for health workers, especially for nurses. Moreover, Malaysia is actively positioning the country as the medical tourism 
destination within the ASEAN market and the Middle East. In 2018, the industry recorded a revenue of about RM1.5 billion (MHTC: Malaysian Healthcare Travel Council, 2020). As a revenue-generating industry, the need for adequate nursing staff becomes paramount, especially in maintaining quality healthcare services in private hospitals. In fact, in one study among international patients, the findings showed that the hospital and the staff are perceived as the important factors of medical tourism (Manaf et al., 2015).

High turnover, coupled with nurse migration, has led to shortage of nurses in Malaysia (Atefi, Abdullah \& Wong, 2016; Alam \& Mohammad, 2010). Malaysian nurses' leaving the country (Barnett, Namasivayam \& Narudin, 2010) seeking job opportunities in countries like Saudi Arabia, United Kingdom and Australia are partly because those countries provide higher pay and lucrative benefits. In Saudi Arabia alone, there were between 7,000 to 8,000 Malaysian nurses working back in 2013 (The Star, 2013) and more recently, Singapore appears as an emerging destination for Malaysian nurses promising better salary (Pillay, 2017). Therefore, competition is intense among private hospitals to secure an adequate pool of skilled nursing staff. Although some of the hospitals offer competitive salary scheme to attract nurses, this does not address the issue in the long run. In fact, according to Aiken et al., (2001) "twentyfirst-century health care has created vast opportunities for nurses, but the hospitals are ill prepared to compete for and retain the most qualified nurses."

\section{Review of Literature}

As nurse shortage and nurse retention become an on-going challenge to many, substantial studies have examined the factors that influence nurses' intention to stay or leave (Kim \& Hwang, 2011). Intention to stay is nurse's perceived likelihood of staying within the organisation and is directly and positively related to retention (Tourangeau \& Cranley, 2006). Studies on health worker's retention have emphasised that without an effective strategy, the shortage of health workers at large would persist. Of that, one way to combat manpower shortage and high turnover are to develop and implement effective incentive schemes (WHO: World Health Organisation, 2008). Formulating a successful incentive plan is considered crucial that WHO has published an incentive guideline for healthcare professionals. For instance, besides pay, individuals may appreciate the flexible working arrangements that enables to balance work-life demands. Younger nurses for example, may look forward to further educational opportunities to enhance their nursing skills.

Reward and incentives function as a motivational factor related to employees' intention to stay, job satisfaction and performance (Zurn, Dolea \& Stilwell, 2005). It is a general perception that financial incentives are more likely to improve retention. However, based on the International Council of Nurses (2008) research report, non-financial incentives have an equal impact as much as financial incentives have on employees' behavioural outcome. Empirical studies have shown, nurses themselves have highlighted provision of nonfinancial incentives as a suggestion to encourage retention (Dawson et al., 2014). Others like Torgerson et al., (2012) have found incentives as a criterion that influences nurses' decision to enter the healthcare sector and where to work and practice. With a properly formulated incentives, hospitals can achieve adequate nursing manpower while achieving its goals.

A study by Ramoo, Abdullah \& Piaw (2013) among registered nurses in public hospitals in Malaysia showed a significant relationship between job satisfaction and nurses' intention to leave their current employment. The authors posit organisations should promote retention through greater management decision-making capabilities, opportunities for further education and flexible working environment. Similarly, Barnett, Namasivayam \& Narudin (2010) reported shortage of nurses could be addressed by improving retention and creating a safe and encouraging work environment. Retaining an existing employee is far more efficient human resource strategy than recruiting a new one because those who are motivated to stay will have a higher likelihood of staying. Also, it prevents high replacement cost, low motivation among employees due to heavy workload, compromised patient care and medical error which could lead to medico-legal cases. However, there is a paucity of research examining the impact of non-financial incentives among nurses in the Malaysian context. The influence of non-financial incentives on intention to stay has been researched by many in previous studies as an effective retention strategy among health workers (Mulenga, 2011; WillisShattuck et al., 2008; Dambisya, 2007; Mathauer \& Imhoff, 2006). The findings from these past studies may have resulted from the cultural norm, values, and other demographic factors. Therefore, this study is expected to provide findings based on the Malaysian context. 
Specifically, it aims to examine the impact of nonfinancial incentives on intention to stay among nurses in the private hospitals in Malaysia.

Incentives play a critical role in the healthcare industry as a tool to recruit, retain and motivate health workers. Mathauer \& Imhoff (2006) defined incentive as "an available means applied with the intention to influence the willingness of nurses and physicians to exert and maintain an effort towards attaining organisational goals". This can be supported by the Theory of Expectancy (Vroom, 1964) that focuses on the outcome. For instance, individual may seek employment in an organisation with intention that their contributions are valued, hence if these expectations are met then the likelihood of intend to stay increases. To understand health workers career decision, George, Gow \& Bachoo (2013) found it is essential to have a broad range of attractive non-financial incentives to encourage health workers retention. Non-financial incentives are referred to provision of work autonomy, recognition of work and flexibility in working time (Dawson et al., 2014; Caldwell \& Kingma, 2007; Zurn, Dolea \& Stilwell, 2005; Kingma, 2003). Although, significant literature on implementation of nonfinancial incentives were studied in fund limited and rural areas (Dambisya, 2007; Mathauer \& Imhoff, 2006; Munga \& Mbilinyi, 2008), the importance of nonfinancial incentives is not limited only to poorly resourced nations, it is also practised where staff are able to maintain a high standard of living in wellresourced countries (Alamri \& Zuraikat, 2011; WHO, 2008).

A large-scale survey among nurses in China on predictors of hospital nurses' intent to stay (Wang et al., 2012), provides support for praise/recognition, and professional advancement opportunities as the significant factors of nurses' intent to stay. Others have echoed similar findings, for example, a qualitative study conducted among long-term nurses in Canadian health workforce showed the nurses highly value educational opportunities as a factor which influences retention (Leurer, Donnelly \& Domm, 2007). According to WHO (2008), access to formal and informal education and training are highly valued by health professionals, as such the lack of professional development could contribute to job dissatisfaction among employees (Henderson \& Tulloch, 2008). Additionally, Vroom (1964) posits that the perception of future advancement opportunities within the organisation acts as the motivation for employees to perform according to expectations. In an overview of incentives for healthcare providers by Torgerson et al., (2012) promotional opportunities along with clinical supervision and educational programmes were identified as non-financial incentives. Foong-Ming (2008) refers internal promotion as an evidence of formal recognition from the organisation, which results in better pay rise, challenging work, autonomy, status and responsibility. It is also positively linked to job satisfaction (Igbaria \& Greenhaus, 1992), behavioural outcome such as organisational commitment (Schwarzwald, Koslowsky \& Shalit, 1992) and retention (Gaertner \& Nollen, 1989; Allen, Shore \& Griffeth, 2003; Hayes et al., 2006).

Positive and healthy working relationships with the supervisor and management stimulates better retention. As stated by Kilpert \& Jooste (2002), nurses require positive feedback and support that fosters the feeling of self-worth, especially when empowered with opportunities to use nursing skills. Indeed, the supervisor's or manager's support has been suggested as an important factor in managing employees (Tourangeau et al., 2010; Dawson et al., 2014). Mainly because a good leader would support and motivate his/her subordinates to bring out the best in them, while addressing their weaknesses for better work performance. Apart from that, management support allowing nurses' participation in decision making pertains to patient care or to matters that nurses had a solution to address (Dawson et al., 2014) may instil the positive perception of they are valued.

Autonomy embeds a sense of responsibility to provide safe patient care, as such the nurses would be meticulous and careful in every job process since the organisation has placed trust on their clinical practice ability and judgement. Substantial studies have confirmed the benefits of autonomy, primarily on nurses' retention (e.g. Gess, Manojlovich \& Warner, 2008; Hayes et al., 2006; Kramer \& Schmalenberg, 2003). As a result, nurses experience increased respect, status and recognition (Hinshaw, 2002), reduced turnover rates and burnout (McClure et al., 2002; Vahey et al., 2004; Hayes et al., 2006). Besides, finding by Mulenga (2011) on the influence of non-financial incentives on retention in Zambia, showed the availability of essential equipment, tools and supplies as one of the important factors of nurses' retention. Similarly, Tourangeau et al., (2010) found one of the themes that emerged from the focus group was the 
condition of the work environment as an important retention factor. If the health workers found that the equipment necessary to perform their duties were inadequate or non-existent, it could lead to turnover (Adzei \& Atinga, 2012).

In recent years, extant literature has reported workfamily conflict is related to decrease in employees' performance, increase in absenteeism, job dissatisfaction which subsequently results in intention to leave (Butler \& Skattebo, 2004; Dawson et al., 2014). Managing workfamily demands impact nurses well-being such as burnout, health deterioration and decrease in life satisfaction. A qualitative study among registered nurses in Australia (Dawson et al., 2014) showed uncompromising shifts as being demotivating and it is perceived as lack of management support. As nursing work schedule involves shift rotation, authors in this area of studies have found options such as family-friendly policies and flexible shifts are able to establish improved recruitment (Barriball et al., 2007) and nurse retention (Chenoweth et al., 2010). Similarly, reasonable workloads and manageable nursepatient ratios were the two most significant incentives found to increase the likelihood of nurses intend to remain employed (Tourangeau et al., 2013). Likewise, Ellenbecker et al., (2007) were in view that reducing nurses' job demand would reduce nurses' stress and workloads demand. These can be attained through reduced paperwork by shifting nurses' functional tasks that do not require nursing expertise or skills to support staff.

\section{METHODOLOGY}

\section{Design}

This study administered descriptive research with a cross-sectional approach to examine the relationship between non-financial incentives and intention to stay among nurses in private hospitals in Malaysia.

\section{Sample}

A self-reported questionnaire was distributed to all private hospitals in the Klang Valley, through the human resource department or the nurse manager. A final sample of 153 staff nurses participated in this study.

\section{Research Instruments}

The research questionnaire consists of three sections. The first section includes items measuring non-financial incentives. The second section measures the nurses' intention to stay. The last part of the questionnaire measures demographic items of interest.
The instruments for non-financial incentives was measured with eight dimensions. Education, training and professional development (ETP) was measured using nine items adapted from Liu (2004) and Krishnasamy (2013). The scale has items such as "I am given the necessary training and development to do my work". Recognition was measured with eight items adapted from Blegen et al., (1992) and Ramasodi (2012). The scale has items such as "achievements are announced in the hospital newsletter". Promotional opportunities was measured with Job Descriptive Index (JDI) adapted from Smith, Kendall \& Hulin (1969). The scale consists of five items such as "my organisation offers excellent career opportunities to employees who are strong performers". Flexible working arrangements was measured using six items adapted from Rau \& Hyland (2002) and Liu (2004). Example of item is "my working pattern/schedule allows me to balance between family, leisure, and health". Autonomy and CONP (Control Over Nursing Practise) consist of ten items adapted from Rafferty, Ball \& Aiken (2001) and Gerber et al., (1990), examples of items are "I have enough flexibility in my job to do what is necessary to provide good service to my patients" and "this organisation supports new and innovative ideas about patient care". Manageable workload comprises of ten items adapted from Leiter, Gascón \& Martínez-Jarreta (2010) and Lake (2002). The items include "I have sufficient time for each patient". Management and supervisor support were measured using five items adapted from Bearden \& Netemeyer, (1999); Graen \& Scandura, (1987); Farley \& Nyberg (1990); and Lake (2002). Example of the item included "I receive enough feedback from my supervisor on how well I am doing". As for the work environment dimension, the items were adapted from Morgeson \& Humphrey (2006) and Delobelle et al., (2011). The items included are "my job takes place in an environment free from health hazards" and "I have the equipment I need to do my job properly". Finally, intention to stay was measured with five items adapted from intent to stay scale by Wolfgang (1988) and Kaewboonchoo et al., (2014). The scale has included items such as "I rarely think about leaving this organisation to work somewhere else". All the items were rated on 5-point Likert Scale with "1" being "strongly disagree" to "5" being "strongly agree".

\section{RESULTS}

In this study, the collected data was analysed using 
SPSS software version 23. The following section provides the descriptive analysis of demographic characteristics of the respondents, research variables statistic and the findings of regression analysis.

\section{Sample Profile}

Nursing is predominantly taken up by female, thus it explains the high percentage of female respondents found in the study, 95.4\% $(\mathrm{n}=146)$. Much of the respondents of the study belonged to the 21-25 years age group $(41.2 \%)$, followed by $26-30$ years age group (30.7\%). Following the criteria established for sampling frame, all respondents were registered nurses $(\mathrm{RN})$ with diploma in nursing $(97.4 \%)$ while $2.6 \%$ having additional qualification of degree in nursing. As for the job tenure, $48.4 \%$ of respondents have reported 1-5 years of job tenure, followed by $25.5 \%$ of respondents having under a year of job tenure. $69.3 \%$ of the respondents are married, with $44.4 \%$ reported of having children. Most of the respondents are attached to medical department (15.7\%), followed by accident and emergency department (13.7\%) and obstetrics and gynaecology department (13.1\%).

\section{Table 1: Respondents Profile ( $n=153)$}

\begin{tabular}{|c|c|c|c|}
\hline $\begin{array}{l}\text { Measurement } \\
\text { variables }\end{array}$ & & Frequency & Percentage \\
\hline \multirow[t]{2}{*}{ Gender } & Female & 146 & 95.4 \\
\hline & Male & 7 & 4.6 \\
\hline \multirow[t]{6}{*}{ Age } & $21-25$ years & 63 & 41.2 \\
\hline & $26-30$ years & 47 & 30.7 \\
\hline & $31-35$ years & 16 & 10.5 \\
\hline & $36-40$ years & 14 & 9.2 \\
\hline & $41-45$ years & 8 & 5.2 \\
\hline & $\begin{array}{c}\text { More than } 45 \\
\text { years }\end{array}$ & 5 & 3.3 \\
\hline \multirow[t]{2}{*}{ Marital status } & Single & 47 & 30.7 \\
\hline & Married & 106 & 69.3 \\
\hline \multirow{6}{*}{$\begin{array}{l}\text { Number of } \\
\text { children }\end{array}$} & No Children & 85 & 55.6 \\
\hline & 1 child & 28 & 18.3 \\
\hline & 2 children & 21 & 13.7 \\
\hline & 3 children & 10 & 6.5 \\
\hline & 4 children & 8 & 5.2 \\
\hline & 5 children & 1 & 0.7 \\
\hline
\end{tabular}

\begin{tabular}{|c|c|c|c|}
\hline \multirow{2}{*}{$\begin{array}{l}\text { Highest level of } \\
\text { education }\end{array}$} & Diploma & 149 & 97.4 \\
\hline & Degree & 4 & 2.6 \\
\hline \multirow[t]{5}{*}{ Years in service } & Less than 1 year & 39 & 25.5 \\
\hline & $1-5$ years & 74 & 48.4 \\
\hline & $6-10$ years & 18 & 11.8 \\
\hline & $11-15$ years & 20 & 13.1 \\
\hline & $21-25$ years & 2 & 1.3 \\
\hline \multirow{12}{*}{$\begin{array}{l}\text { Current working } \\
\text { department }\end{array}$} & Medical & 24 & 15.7 \\
\hline & Surgery & 18 & 11.8 \\
\hline & $O \& G$ & 20 & 13.1 \\
\hline & ICU & 12 & 7.8 \\
\hline & $\mathrm{CCU}$ & 4 & 2.6 \\
\hline & NICU & 9 & 5.9 \\
\hline & OR & 15 & 9.8 \\
\hline & Ortho & 8 & 5.2 \\
\hline & Paeds & 16 & 10.5 \\
\hline & Oncology & 4 & 2.6 \\
\hline & $A \& E$ & 21 & 13.7 \\
\hline & Others & 2 & 1.3 \\
\hline \multirow{6}{*}{$\begin{array}{l}\text { Current job } \\
\text { position }\end{array}$} & Staff nurse & 122 & 79.7 \\
\hline & Senior staff nurse & 11 & 7.2 \\
\hline & Junior ward sister & 8 & 5.2 \\
\hline & Ward sister & 4 & 2.6 \\
\hline & Nurse manager & 6 & 3.9 \\
\hline & $\begin{array}{l}\text { Chief nursing } \\
\text { manager }\end{array}$ & 2 & 1.3 \\
\hline
\end{tabular}

\section{Descriptive Statistics of Study Variables}

The descriptive statistics of research variables in terms of the mean and standard deviation are presented in Table 2. Also, Pearson correlation analysis was computed among the dimensions of non-financial incentives and intention to stay on 153 data. The standard deviations of all variables are within the value of 1 , suggesting they are not dispersed too much from the mean value. Pearson correlation indicates there are significant positive associations among all the research variables. 
Table 2: Descriptive Statistics and Pearson Correlation Coefficient Values of Study's Variables (n=153)

\begin{tabular}{|c|c|c|c|c|c|c|c|c|c|c|c|}
\hline & Mean & SD & 1 & 2 & 3 & 4 & 5 & 6 & 7 & 8 & 9 \\
\hline 1. ITS & 3.607 & 0.725 & 1 & & & & & & & & \\
\hline 2. ETP & 3.551 & 0.687 & $0.558^{* *}$ & 1 & & & & & & & \\
\hline 3. Rec & 3.423 & 0.695 & $0.567^{* *}$ & $0.701^{* *}$ & 1 & & & & & & \\
\hline 4. PO & 3.390 & 0.541 & $0.538^{* *}$ & $0.715^{* *}$ & $0.707^{* *}$ & 1 & & & & & \\
\hline 5. FWA & 3.585 & 0.711 & $0.561^{* *}$ & $0.698^{* *}$ & $0.713^{* *}$ & $0.654^{* *}$ & 1 & & & & \\
\hline 6. $\mathrm{AC}$ & 3.474 & 0.569 & $0.571^{* *}$ & $0.718^{* *}$ & $0.741^{* *}$ & $0.645^{* *}$ & $0.713^{* *}$ & 1 & & & \\
\hline 7. MW & 3.392 & 0.799 & $0.666^{* *}$ & $0.594^{* *}$ & $0.664^{* *}$ & $0.543^{* *}$ & $0.737^{* *}$ & $0.695^{* *}$ & 1 & & \\
\hline 8. MSS & 3.494 & 0.576 & $0.575^{* *}$ & $0.646^{* *}$ & $0.560^{* *}$ & $0.563^{* *}$ & $0.589^{* *}$ & $0.718^{* *}$ & $0.664^{* *}$ & 1 & \\
\hline 9. WE & 3.607 & 0.541 & $0.602^{* *}$ & $0.698^{* *}$ & $0.562^{* *}$ & $0.537^{* *}$ & $0.619^{* *}$ & $0.694^{* *}$ & $0.618^{* *}$ & $0.721^{* *}$ & 1 \\
\hline
\end{tabular}

** correlation is significant at the 0.01 level

Note:

ITS - Intention to Stay, ETP - Education, Training and Professional Development, Rec - Recognition, PO - Promotional Opportunities, FWAs Flexible Working Arrangements, AC - Autonomy and Control Over Nursing Practice. MW - Manageable Workload, MSS - Management and Supervisory Support, WE - Work Environment

\section{Regression Analysis}

Multiple regression analysis was carried out to assess the statistical significance of the relationship among the variables. Essentially, it is to examine the impact of eight dimensions of non-financial incentives on nurses' intention to stay. Table 3 presents a summary of multiple regression analysis for all the research variables of the study. The confidence level established for the statistical analysis is $95 \%$. All the variables met the VIF value of $<5$ (Hair, Ringle \& Sarstedt, 2011). Hence, collinearity is not an issue in this model. The $\mathrm{R}^{2}$ value of 0.543 indicates $54 \%$ of the variance in intention to stay can be predicted by the eight dimensions of nonfinancial incentives. Based on the Table 3, promotional opportunities $(\beta=0.260, p<0.05)$, manageable workload $(\beta=0.442, p<0.05)$ and work environment $(\beta=0.204, p<0.05)$ are positively related to intention to stay. Therefore, $\mathrm{H} 3, \mathrm{H} 6$ and $\mathrm{H} 8$ are supported.
Table 3: Results of Regression Analysis - Model Summary

\begin{tabular}{|l|l|c|c|c|}
\hline \multicolumn{2}{|l|}{ Hypothesis } & $\begin{array}{c}\text { Standardized } \\
\text { Beta }\end{array}$ & $\boldsymbol{p}$-value & VIF \\
\hline H1 & $\begin{array}{l}\text { Education, training and } \\
\text { professional development } \rightarrow \\
\text { Intention to stay }\end{array}$ & 0.000 & 0.996 & 3.276 \\
\hline H2 & Recognition $\rightarrow$ Intention to stay & 0.074 & 0.457 & 3.119 \\
\hline H3 & $\begin{array}{l}\text { Promotional opportunities } \rightarrow \\
\text { Intention to stay }\end{array}$ & 0.260 & 0.007 & 2.843 \\
\hline H4 & $\begin{array}{l}\text { Flexible working } \\
\text { arrangements } \rightarrow \text { Intention to stay }\end{array}$ & -0.108 & 0.298 & 3.352 \\
\hline H5 & $\begin{array}{l}\text { Autonomy and control } \\
\text { over nursing practice } \rightarrow \text { Intention } \\
\text { to stay }\end{array}$ & -0.054 & 0.614 & 3.635 \\
\hline H6 & $\begin{array}{l}\text { Manageable workload } \rightarrow \\
\text { Intention to stay }\end{array}$ & 0.442 & 0.000 & 2.947 \\
\hline H7 & $\begin{array}{l}\text { Management and supervisory } \\
\text { Support } \rightarrow \text { Intention to stay }\end{array}$ & 0.039 & 0.687 & 2.869 \\
\hline H8 & $\begin{array}{l}\text { Work environment } \rightarrow \text { Intention to } \\
\text { stay }\end{array}$ & 0.204 & 0.031 & 2.763 \\
\hline & R & & 0.543 & \\
\hline & Adjusted R & 0.517 & \\
\hline & Sig. F Change & & 2.065 & \\
\hline & Durbin-Wattson & & \\
\hline
\end{tabular}




\section{DISCUSSION}

The main purpose of this study is to examine the relationship of non-financial incentives on the intention to stay among nurses in private hospitals in Malaysia. The findings of the present study revealed promotional opportunities is positively and significantly related to nurses' intention to stay. The finding is similar to others (e.g. Gaertner \& Nollen, 1989; Allen, Shore \& Griffeth, 2003; Hayes et al., 2006; Takahashi, 2006). Also, following similar findings as Tourangeau et al., (2013) and Ellenbecker et al., (2007), manageable workload is positively and significantly related to intention to stay. Maintaining adequate nursing staff minimises the tendency of nurses being overburdened with excessive responsibilities that could affect their physical and emotional well-being and the quality of patient care. Likewise, work environment is positively and significantly related to employee's intention to stay, as supported by others (Snow et al., 2011; Mulenga, 2011; Tourangeau et al., 2010). This result further supports Herzberg's Motivation-Hygiene Theory which suggests that the absence of conducive work environment may leads to dissatisfaction among employees. Therefore, organisations that provide positive work environment may influence higher likelihood of nurse intention to stay.

The insignificant findings of the relationships between education, training and professional development, recognition, control over nursing practice, flexible working arrangements, management and supervisory support on nurses' intention to stay may be related to the demographic profile of the nurses that participated in this study. The demographic profile of this study revealed $71.9 \%$ of the respondents belonged to the $21-30$ years age group. Thus, these young nurses are possibly serving their educational bond or nearing the completion of the bond period. In Malaysia, those students who are funded by private hospitals for nursing education are liable for compulsory educational bond between five to eight years with the hospital (Tang \& Idris, 2016). As such, committing to further professional courses such as postbasic training may increase the number of years bonded with the hospital. These young nurses may not want to add more commitment to their bond preventing their opportunity for employment elsewhere within the industry. Furthermore, the sample were collected from Klang Valley, and it may be considered that these young nurses living in the urban area would prefer financial-based reward than incentives such as acknowledgement letter. In fact, De Gieter et al. (2006) found in their study, that younger nurses prefer promotional opportunities as more rewarding. In terms of autonomy, less experienced nurses are still learning to adapt demanding nursing career. Therefore, having or given additional responsibility could intimidate them in making important decision pertaining to patient's well-being as well as nursing practice. Although flexible work arrangements benefit the employer in retaining its employees (Dawson et al., 2014; Lewis, 2003; Becker, McCutcheon \& Hegney, 2010; Tourangeau et al., 2010), it may aggravate the work-life conflict. For instance, flexibility in the timing of work could make employees being asked to clock in during unsocial hours (Russell, O'Connell \& McGinnity, 2009) that nurses do not consider as an incentive. Furthermore, nurses are aware of the duty roster rotation that allows them to seek the flexibility needed for non-work-related demands.

In this study, two distinct demographic variables may have influenced the study's outcome. The sample is taken from the urban setting of Klang Valley hospitals, and more than two-third of the respondents $(71.9 \%)$ are aged 30 years or below. Therefore, these variables may have contributed different opinions and views of non-monetary incentives. Evidently, Lavoie-Tremblay et al., (2010) have reported that those young nurses belong to Gen-Y cohort demonstrate different attitudes and values towards their work, which may affect their retention. Apart from that, it is essential to take into consideration of values, cultural factor and behavioural aspect when developing reward system as employees from different cultural background prefers different types of incentives (Chiang \& Birtch, 2012).

\section{CONCLUSION}

WHO's guidelines on incentives for healthcare professionals have indicated there is no one-size-fits-all approach when developing incentive program, instead policymakers should tailor incentives according to the targeted group of employees. Therefore, the management of hospitals need to be attentive when implementing incentives following the targeted group, as different group of nurses may have distinct respond to specific nonfinancial incentives. It is recommended to replicate the present study amongst different generational cohort and beyond urban demographic. Also, different methods, such as focus group or in-depth interview is suggested to gauge deeper understanding of the influential role of nonfinancial incentives on nurses' behavioural outcomes.

\section{Conflict of Interests}

The authors declare that they have no conflict of interest. ACKNOWLEDGEMENT

This research did not receive any specific grant from funding agencies in the public, commercial, or not-forprofit sectors. 


\section{REFERENCES}

Adzei, F.A. \& Atinga, R.A. (2012). Motivation and retention of health workers in Ghana's district hospitals: Addressing the critical issues. Journal of Health Organisation and Management, 26(4), pp 467-485.

Aiken, L.H., Clarke, S.P., Sloane, D.M., Sochalski, J.A., Busse, R., Clarke, H., Giovannetti, P., Hunt, J., Rafferty, A.M. \& Shamian, J. (2001). Nurses' reports on hospital care in five countries. Health Affairs, 20(3), pp 43-53.

Alam, M.M. \& Mohammad, J.F. (2010). Level of job satisfaction and intent to leave among Malaysian nurses. Business Intelligence Journal,3(1), pp 123-137.

Alamri, M. \& Zuraikat, N. (2011). Financial incentives system for nursing in the Kingdom of Saudi Arabia. Journal of Accounting and Finance, 11(2), pp 53-57.

Al-Dossary, R.N. (2018). The Saudi Arabian 2030 vision and the nursing profession: the way forward. International Nursing Review, 65(4), pp 484-490.

Allen, D.G., Shore, L.M. \& Griffeth, R.W. (2003). The role of perceived organizational support and supportive human resource practices in the turnover process. Journal of Management, 29(1), pp 99-118.

AlYami, M.S. \& Watson, R. (2014). An overview of nursing in Saudi Arabia. Journal of Health Specialties, 2(1), pp 10-12.

Atefi, N., Abdullah, K.L. \& Wong, L.P. (2016). Job satisfaction of Malaysian registered nurses: A qualitative study. Nursing in Critical Care, 21(1), pp 8-17.

Barnett, T., Namasivayam, P. \& Narudin, D.A.A., (2010). A critical review of the nursing shortage in Malaysia. International Nursing Review, 57(1), pp 32-39.

Barriball, K.L., Coopamah, V., Roberts, J. \& Watts, S. (2007). Evaluation of return to practice: The views of nurse returnees from three NHS hospital trusts. Journal of Nursing Management, 15(4), pp 433-441.

Bearden, W.O. \& Netemeyer, R.G. (1999). Handbook of marketing scales: Multi-item measures for marketing and consumer behavior research. $2^{\text {nd }}$ Edition. Thousand Oaks, California, USA: Sage publications.

Becker, M.S., McCutcheon, H. \& Hegney, D. (2010). Casualization in the nursing workforce-the need to make it work. Australian Journal of Advanced Nursing, 28(1), pp 45-51.

Blegen, M.A., Goode, C.J., Johnson, M., Maas, M.L., McCloskey, J.C. \& Moorhead, S.A. (1992). Recognizing staff nurse job performance and achievements. Research in Nursing \& Health, 15(1), pp 57-66.

Butler, A.B. \& Skattebo, A. (2004). What is acceptable for women may not be for men: The effect of family conflicts with work on job-performance ratings. Journal of Occupational and Organizational Psychology, 77(4), pp $553-564$.

Caldwell, P. \& Kingma, M. (2007). Incentives and the recruitment/retention of nurses, a paper presented at National Experiences in Assessing and Reducing Shortcomings and Negative Trends affecting Human Resources of the Health System: An International Symposium on Health Workforce. Lisbon: International Centre for Human Resources in Nursing.

Chenoweth, L., Jeon, Y.H., Merlyn, T. \& Brodaty, H. (2010). A systematic review of what factors attract and retain nurses in aged and dementia care. Journal of Clinical Nursing, 19(1-2), pp 156-167.

Chiang, F.F. \& Birtch, T.A. (2012). The performance implications of financial and non-financial rewards: an Asian Nordic comparison. Journal of Management Studies, 49(3), pp 538-570.

Dambisya, Y.M. (2007). A review of non-financial incentives for health worker retention in east and southern Africa. South Africa: Health Systems Research Group, Department of Pharmacy, School of Health Sciences, University of Limpopo. 
Dawson, A.J., Stasa, H., Roche, M.A., Homer, C.S. \& Duffield, C. (2014). Nursing churn and turnover in Australian hospitals: Nurses perceptions and suggestions for supportive strategies. BMC Nursing, 13(1), p 11.

De Gieter, S., De Cooman, R., Pepermans, R., Caers, R., Du Bois, C. \& Jegers, M. (2006). Identifying nurses' rewards: a qualitative categorization study in Belgium. Human Resources for Health, 4(1), p 15.

Delobelle, P., Rawlinson, J.L., Ntuli, S., Malatsi, I., Decock, R. \& Depoorter, A.M. (2011). Job satisfaction and turnover intent of primary healthcare nurses in rural South Africa: A questionnaire survey. Journal of Advanced Nursing, 67(2), pp 371-383.

Efendi, F., Mackey, T.K., Huang, M.C. \& Chen, C.M. (2017). IJEPA: gray area for health policy and international nurse migration. Nursing Ethics, 24(3), pp 313-328.

Ellenbecker, C.H., Samia, L., Cushman, M.J. \& Porell, F.W. (2007). Employer retention strategies and their effect on nurses' job satisfaction and intent to stay. Home Health Care Services Quarterly, 26(1), pp 43-58.

Farley, M.J. \& Nyberg, J. (1990). Environment as a major element in nursing administration practice theory development. Nursing \& Health Care: Official Publication of the National League for Nursing, 11(10), pp 532-535.

Foong-ming, T. (2008). Linking career development practices to turnover intentions: The mediator of perceived organisational support. Journal of Business and Public Affairs, 2(1), pp 1-16.

Gaertner, K.N. \& Nollen, S.D. (1989). Career experiences, perceptions of employment practices, and psychological commitment to the organization. Human Relations, 42(11), pp75-991.

George, G., Gow, J. \& Bachoo, S. (2013). Understanding the factors influencing health-worker employment decisions in South Africa. Human Resources for Health, 11(1), pp 15.

Gerber, R., Murdaugh, C., Verran, J. \& Milton, D. (1990). Control over nursing practice scale. In National Conference on Instrumentation in Nursing. Tucson, AZ. University of Arizona.

Gess, E., Manojlovich, M. \& Warner, S. (2008). An evidence-based protocol for nurse retention. Journal of Nursing Administration, 38(10), pp 441-447.

Graen, G.B. \& Scandura, T.A. (1987). Toward a psychology of dyadic organizing. Research in Organizational Behavior, 9, pp 175-208.

Hair, J.F., Ringle, C.M. \& Sarstedt, M. (2011). PLS-SEM: Indeed a silver bullet. Journal of Marketing Theory and Practice, 19(2), pp 139-152.

Hassan, M. (2017). Strategies of improving the nursing practice in Saudi Arabia. Journal of Health Education Research \& Development, 5(2), pp 1-4.

Hayes, L.J., O’Brien-Pallas, L., Duffield, C., Shamian, J., Buchan, J., Hughes, F., Laschinger, H.K.S., North, N. \& Stone, P. W. (2006). Nurse turnover: A literature review. International Journal of Nursing Studies, 43(2), pp 237263.

Henderson, L.N. \& Tulloch, J. (2008). Incentives for retaining and motivating health workers in Pacific and Asian countries. Human Resources for Health, 6(1), p 18.

Hinshaw A.S. (2002). Building magnetism into health organizations. In M.L. McClure \& A.S. Hinshaw (Eds.), Magnet hospitals revisited ( $\mathrm{pp} 83-102$ ). Washington, DC: American Nurses Publishing.

Igbaria, M. \& Greenhaus, J.H. (1992). The career advancement prospects of managers and professionals: Are MIS employees unique? Decision Sciences, 23(2), pp 478-499.

International Council of Nurses (2008), Guidelines: Incentives for Health Professionals. Global Health Workforce Alliance. Retrieved from: https:/www.who.int/workforcealliance /documents/Incentives Guidelines\%20EN.pdf. 
Juraschek, S.P., Zhang, X., Ranganathan, V. \& Lin, V.W. (2012). United States registered nurse workforce report card and shortage forecast. American Journal of Medical Quality, 27(3), pp 241-249.

Kaewboonchoo, O., Yingyuad, B., Rawiworrakul, T. \& Jinayon, A. (2014). Job stress and intent to stay at work among registered female nurses working in Thai hospitals. Journal of Occupational Health, 56(2), pp 93-99.

Kilpert, O. \& Jooste, K. (2002). The role of management in promoting a motivational work setting for nurses. Health SA Gesondheid, 7(2), pp 14-24.

Kim, E.K. \& Hwang, J.I. (2011). Characteristics associated with intent to stay among Quality Improvement nurses. International Nursing Review, 58(1), pp 89-95.

Kingma, M. (2003). Economic incentive in community nursing: attraction, rejection or indifference? Human Resources for Health, 1(1), p 2 .

Kramer, M. \& Schmalenberg, C.E. (2003). Magnet hospital staff nurses describe clinical autonomy. Nursing Outlook, 51(1), pp 13-19.

Krishnasamy. N. (2013). The moderating role of spirituality on job satisfaction and intention to leave: A study among nurses in Malaysia. MBA Dissertation, Universiti Sains Malaysia.

Lake, E.T. (2002). Development of the practice environment scale of the Nursing Work Index. Research in Nursing \& Health, 25(3), pp 176-188.

Lavoie-Tremblay, M., Leclerc, E., Marchionni, C. \& Drevniok, U. (2010). The needs and expectations of generation Y nurses in the workplace. Journal for Nurses in Professional Development, 26(1), pp 2-8.

Leiter, M.P., Gascón, S. \& Martínez-Jarreta, B. (2010). Making sense of work life: A structural model of burnout. Journal of Applied Social Psychology, 40(1), pp 57-75.

Leng, C.H. \& Barraclough, S. (2007). The growth of corporate health care in Malaysia. In Leng, C.H. \& Barraclough, S. (Eds.), Health Care in Malaysia: The Dynamics of Provision, Financing and Access (pp 19-39). London and New York: Routledge.

Leurer, M.D., Donnelly, G. \& Domm, E. (2007). Nurse retention strategies: advice from experienced registered nurses. Journal of Health Organization and Management, 21(3), pp 301 -319.

Lewis, S. (2003). Flexible working arrangements: Implementation, outcomes and management. International Review of Industrial and Organizational Psychology, 18, pp 1-28.

Liu, W. (2004). Perceived organizational support: Linking human resource management practices with important work outcomes. Doctoral Dissertation, University of Maryland.

Malaysian Healthcare Travel Council, MHTC, Number of healthcare travellers and revenue between 2011-2018. Retrieved from: https://www.mhtc.org.my/.

Manaf, N.H.A., Hussin, H., Kassim, P.N.J., Alavi, R. \& Dahari, Z. (2015). Country perspective on medical tourism: the Malaysian experience. Leadership in Health Services, 28 (1), pp 43-56.

Mathauer, I. \& Imhoff, I. (2006). Issue with health worker motivation in Africa: The role of non-financial incentives and human resource management tools. Human Resources for Health, 4(1), p 24.

McClure, M.L., Poulin, M.A., Sovie, M.D. \& Wandelt, M.A. (1983). Magnet hospitals: Attraction and retention of professional nurses. Retrieved from: http://citeseerx.ist.psu.edu/viewdoc/download?doi $=10.1 .1 .487 .3161 \&$ rep=rep1\&type=pdf.

Ministry of Health Malaysia, MOH (2014). Health facts 2014. Planning Division, Health Informatics Centre, June 2014 [online]. Retrieved from: https://www.moh.gov.my /moh/resources/Penerbitan/Penerbitan\%20Utama/ 


\section{HEALTH\%20FACTS/HEALTH\%20FACTS\%202014.pdf}

Morgeson, F.P. \& Humphrey, S.E. (2006). The Work Design Questionnaire (WDQ): Developing and validating a comprehensive measure for assessing job design and the nature of work. Journal of Applied Psychology, 91(6), p 1321.

Mulenga, L K. (2011). The influence of non-financial incentives on the retention of nurses in two rural hospitals in the Copperbelt province of Zambia. Master of Public Health Dissertation, University of the Witwatersrand.

Munga, M. \& Mbilinyi, D. (2008). Non-financial incentives and retention of health workers in Tanzania. Dar es Salaam: National Institute for Medical Research.

Newman, K. \& Maylor, U. (2002). The NHS Plan: Nurse satisfaction, commitment and retention strategies. Health Services Management Research, 15(2), pp 93-105.

Oda, H., Tsujita, Y. \& Rajan, S.I. (2018). An analysis of factors influencing the international migration of Indian nurses. Journal of International Migration and Integration, 19(3), pp 607-624.

PEMANDU (2012). Performance Management \& Delivery Unit. Retrieved from: http://etp.pemandu.gov.my/ Overview_of_NKEAs-@-Overview_of_NKEAs.aspx.

Pillay, S. (2017). Will Malaysia face a shortage of nurses by 2020? New Straits Times [online]. $1^{\text {st }}$ January. Retrieved from: https://www.nst.com.my/news/2017/01/201014/will-malaysia-face-shortage-nurses 2020.

Rafferty, A.M., Ball, J. \& Aiken, L.H. (2001). Are teamwork and professional autonomy compatible, and do they result in improved hospital care? BMJ Quality \& Safety, 10(supplementary 2), pp ii32-ii37.

Ramasodi, J.M.B. (2012). Factors influencing job satisfaction among healthcare professionals at South Rand Hospital. Master of Public Health Dissertation, University of Limpopo.

Ramoo, V., Abdullah, K.L. \& Piaw, C.Y. (2013). The relationship between job satisfaction and intention to leave current employment among registered nurses in a teaching hospital. Journal of Clinical Nursing, 22(21-22), pp 3141-3152.

Rau, B.L. \& Hyland, M.A.M. (2002). Role conflict and flexible work arrangements: The effects on applicant attraction. Personnel Psychology, 55(1), pp 111-136.

Russell, H., O'Connell, P.J. \& McGinnity, F. (2009). The impact of flexible working arrangements on work-life conflict and work pressure in Ireland. Gender, Work \& Organization, 16(1), pp 73-97.

Schwarzwald, J.M., Koslowsky. B. \& Shalit (1992). A field study of employees' attitudes and behaviours after promotion decisions. Journal of Applied Psychology, 77, pp 511-514.

Smith, P.C., Kendall, L.M. \& Hulin, C.C. (1969). The measurement of satisfaction in work and retirement. Chicago, Illinois: Rand McNally and Company.

Snow, R.C., Asabir, K., Mutumba, M., Koomson, E., Gyan, K., Dzodzomenyo, M. \& Kwansah, J. (2011). Key factors leading to reduced recruitment and retention of health professionals in remote areas of Ghana: a qualitative study and proposed policy solutions. Human Resources for Health, 9(1).

Takahashi, K. (2006). Effects of wage and promotion incentives on the motivation levels of Japanese employees. Career Development International, 11(3), pp 193-203.

Tang, W.M. \& Idris, A.R. (2016). Nursing practice environment as perceived by the Malaysian private hospital nurses. International e-Journal of Science, Medicine and Education, 10(2), 11-20.

The Star (2013). Malaysian nurses enjoy high salaries in Middle-East. The Star [online]. 30 December. Retrieved from: https://www.thestar.com.my/News/Nation/2013/12/30/Msian-nurses-enjoy-high- salaries-in-Middle-East/ 
Torgerson, R., Lait, J., Armitage, G. D., Linder, J., Hepp, S., Jackson, K. \& Suter, E. (2012). Incentives for Health Care Providers: An Overview of Reviews. Evaluation, Alberta Health Services. Retrieved from: http://www. albertahealthservices.ca/5264.asp.

Tourangeau, A.E. \& Cranley, L.A. (2006). Nurse intention to remain employed: understanding and strengthening determinants. Journal of Advanced Nursing, 55(4), pp 497-509.

Tourangeau, A.E., Cummings, G., Cranley, L.A., Ferron, E.M. \& Harvey, S. (2010). Determinants of hospital nurse intention to remain employed: Broadening our understanding. Journal of Advanced Nursing, 66(1), pp 22-32.

Tourangeau, A.E., Thomson, H., Cummings, G. \& Cranley, L.A. (2013). Generation specific incentives and disincentives for nurses to remain employed in acute care hospitals. Journal of Nursing Management, 21(3), pp 473-482.

Vahey, D.C., Aiken, L.H., Sloane, D.M., Clarke, S. P. \& Vargas, D. (2004). Nurse burnout and patient satisfaction. Medical Care, 42(2 Suppl), pp II57-II66.

Vroom, V.H. (1964). Work and motivation. New York: John Wiley.

Wang, L., Tao, H., Ellenbecker, C.H. \& Liu, X. (2012). Job satisfaction, occupational commitment and intent to stay among Chinese nurses: A cross-sectional questionnaire survey. Journal of Advanced Nursing, 68(3), pp 539-549.

Willis-Shattuck, M., Bidwell, P., Thomas, S., Wyness, L., Blaauw, D. \& Ditlopo, P. (2008). Motivation and retention of health workers in developing countries: A systematic review. BMC Health Services Research, 8(1), p 247.

Wolfgang, A.P. (1988). The health professions stress inventory. Psychological Reports, 62(1), pp 220-222.

World Health Organisation, WHO (2008), Global Health Workforce Alliance. Guidelines on Incentives for Health Professionals, Retrieved from: http://www.who.int/ workforcealliance/knowledge/resources/guidelines healthprofessional/en/.

Zurn, P., Dolea, C. \& Stilwell, B. (2005). Nurse retention and recruitment: Developing a motivated workforce. International Council of Nurses, World Health Organization. 